\title{
Changes in clinical migraine picture and in headache frequency in adolescence. Three year prospective study
}

R Kalashyan

From The European Headache and Migraine Trust International Congress

London, UK. 20-23 September 2012

\section{Background}

The clinical picture of migraine in children was different from that in adolescents. The objective of the study was to examine factors which might contribute to an increase or decrease in headache frequency from the age of 13-16 years old. We compared the clinical findings at the first consultation at the age 13 , and finally at the age of 16 years.

\section{Patients and methods}

A population -based prospective study comprising a screening questionnaire at the age of $13(\mathrm{n}=717$, response rate $-81 \%$ ) by interview and clinical examination of randomly selected 182 children from migraine headache and adolescents with no headache. The patients followed in a Outpatients Pediatric Neurology Clinic between January 2009 December 2011. Finally, at the age of 16 years, $132(73 \%) / 182$ adolescents could be re-examined. We checked the male/female ratio, side of the pain, nature of the pain, vertigo and/or dizziness and daily appearance of attacks.

\section{Results}

The ratio of males was $43,2 \%$ and $34,1 \%$ in that order. Unilaterality of the headaches was $56,6 \%$ and $73,2 \%$, respectively. Pulsating quality was $36,4 \%$ and $47,3 \%$. Vertigo and /or dizziness associated with headache were $10,2 \%$ and $8,9 \%$, and morning dominant attack cases $26,1 \%$ and $14,3 \%$,respectively. Headaches increased clinically significantly in $22 \%$ ( $29 \%$ of girls and $14 \%$ of boys) and decreased in $17 \%$ (12\% of girls and $23 \%$ of boys).

\section{Conclusion}

The present study revealed that the clinical picture of migraine in childhood and adolescents gradually changing to that for adults with aging. There are no reports on the correlation between the clinical picture and aging. Headache of migraine increases in girls, but decreases in boys in adolescence.

Published: 21 February 2013

doi:10.1186/1129-2377-14-S1-P220

Cite this article as: Kalashyan: Changes in clinical migraine picture and in headache frequency in adolescence. Three year prospective study. The Journal of Headache and Pain 2013 14(Suppl 1):P220.
Submit your manuscript to a SpringerOpen ${ }^{\circ}$ journal and benefit from:

- Convenient online submission

- Rigorous peer review

- Immediate publication on acceptance

- Open access: articles freely available online

- High visibility within the field

- Retaining the copyright to your article

Submit your next manuscript at $>$ springeropen.com 